\title{
УДК 354
}

Р. В. Палагусинець,

к.е.н., заступник керівника відділу Управління забезпечення

міжпарламентсъких зб' язків, Апарат Верховної Ради Украӥни

ORCID ID: 0000-0003-1399-7164

DOI: $10.32702 / 2306-6814.2020 .21-22.140$

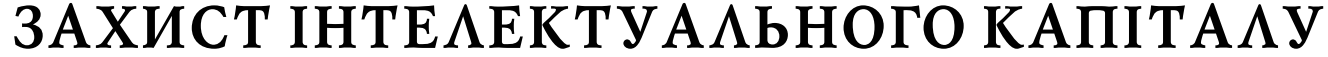 АИП АОМАТИЧНОЇ С УУКБИ}

\author{
R. Palahusynets, \\ $\mathrm{PhD}$ in Economics, Deputy Head of Division Inter-Parliamentary Relations Directorate, \\ Verkhovna Rada (Parliament) of Ukraine
}

\section{PROTECTION OF THE INTELLECTUAL CAPITAL OF THE DIPLOMATIC SERVICE}

Устаттідосліджується захист інтелектуального капіталута власності як один із важливих законодавчих елементів уструктурі дипломатичного апарату України усучасних міжнародних відносинах. Аналізуються та оцінюється правовий та професійно-кваліфікаційний чинники, що впливають на стан, розвиток та формування інтелектуального капіталудипломатичного службовця. Обумовлюється необхідність поліпшення існуючого якісного складу трудового потенціалу з метою підвищення результативності процесів відтворення інтелектуального капіталу Проаналізовано трактування сутності категорії "інтелектуальний капітал", визначено структуру та функції інтелектуальних ресурсів дипломатичного управління в системі ресурсного забезпечення дипломатичного управління, наведена варіативна типологія ресурсів дипломатичного управління. Досліджено проблему управління інтелектуальним капіталом у сфері дипломатичної служби, підготовці та перепідготовці кадрів для дипломатичної та державної служби. Оцінена система дипломатичної служби України на сучасному етапі, яка проходить складний процес її вдосконалення для інтеграції в міжнародне співтовариство. Визначено основні елементи діяльності дипломатичних представництв, де основні аспекти роботи базуються на захисті інтересів та законних прав та свобод громадян країни за кордоном та реалізації безпеки суспільства тадержави. Описано головні характерні ознаки дипломатичного службовця задля формування відповідної ефективної діяльності установи. У дослідженні наведені достовірні службові дані фактичних показників наявності, розподілу, співвідношення кадрового складу дипломатичної служби України за період з 2017-2020 рр. Проаналізовано кількісні показники щодо мовної підготовки та професійного навчання штатних працівників дипломатичної служби. Досліджено, що підготовка дипломатичних кадрів здійснюється Дипломатичною академією України, котрі в інтелектуальному, соціокультурному і професійному відношенні відповідали б реаліям сучасного світу. Доведено, що інтелектуальний капітал на сучасному етапі розглядається в основному з позицій підприємств, однак розвиток цього елементу в галузі дипломатичної служби повинен інтенсивно розвиватися та вдосконалюватися. Досліджено проблеми захисту прав інтелектуальної власностідипломатичної служби.

The article examines the protection of intellectual capital and property as one of the important legislative elements in the structure of the diplomatic apparatus of Ukraine in modern international relations. Legal and professional qualification factors influencing the state, development and formation of intellectual capital of a diplomatic official are analyzed and evaluated. The necessity of improving the existing qualitative composition of labor potential in order to increase the effectiveness of intellectual capital reproduction processes is analyzed. The interpretation of the essence of the category "intellectual capital" is analyzed, the structure and functions of intellectual resources of diplomatic management The problem of intellectual capital management in the field of diplomatic service, training and retraining for diplomatic and civil service is studied. The system of the diplomatic service of Ukraine at the present stage, which is undergoing a complex process of its improvement for integration into the international community, has been assessed. The main elements of the activity of diplomatic missions are determined, where the main aspects of work are based on protection of interests and legal rights and freedoms of citizens of the country abroad and realization of security of society and the state. The main characteristic features of a diplomatic official for the formation of the corresponding effective activity of the institution are described. 
The study provides reliable official data on the actual indicators of availability, distribution, ratio of personnel of the diplomatic service of Ukraine for the period from 2017 to 2020. Analyzed quantitative indicators on language training and vocational training of staff of the diplomatic service. It is investigated that the training of diplomatic personnel is carried out by the Diplomatic Academy of Ukraine, which in intellectual, socio-cultural and professional terms would correspond to the realities of the modern world. It is proved that intellectual capital at the present stage is considered mainly from the standpoint of enterprises, but the development of this element in the field of diplomatic service should be intensively developed and improved. The problems of protection of intellectual property rights of the diplomatic service are investigated.

КлючоВі слова: інтелектуальний капітал, інтелектуальний ресурс, дипломатична служба, захист праъ інтелектуальної Власності, об'єкти інтелектуальної Власності.

Key words: intellectual capital, intellectual resource, diplomatic service, protection of intellectual property rights, intellectual property.

\section{ПОСТАНОВКА ПРОБАЕМИ}

Результативним показником діяльності дипломатичного апарату в основному визначається роллю дипломатичної служби, потенціалом особистості, котра в ній проводить фрахову діяльність, включаючи інтелектуальні здібності дипломатичного службовця, який забезпечує імплементацію належних дипломатичних рішень. Результативність цього процесу знаходиться в прямій залежності від того, наскільки розвинутий, затребуваний та реалізований інтелектуальний капітал дипломатичного службовця людини з урахуванням його розширеного відтворення. Таким чином, забезпечення розширеного відтворення інтелектуального капіталу дипломатичної служби сьогодні - це не тільки засіб та умова розвитку суспільного виробництва, але й пріоритетна мета якісного поліпшення сучасної системи дипломатичного управління.

Дипломатично-управлінську діяльність важко уявити без ресурсного забезпечення, де імплеметація основної мети дипломатичного управління потребує пошук та формування механізмів раціонального розподілу потрібних ресурсів та результативного їх застосування. Теорія дипломатичного управління виділяє декілька різновидів ресурсів державної влади та управління, але в загальноприйнятій типології серед багатьох видів ресурсів саме інтелектуальні ресурси як окрема категорія ресурсів дипломатичного управління не представлені, де у сучасному світі визначальним фрактором являється наявність знань та володіння інформацією.

Зростання ролі інтелектуальної діяльності у розвитку суспільства акцентує увагу на створенні надійної та ефективної системи охорони та захисту прав на об'єкти інтелектуальної власності. Останні роки в Україні захист прав інтелектуальної власності набуває усе більшої гостроти, оскільки масштаби порушення даних прав стрімко зростають. У цьому контексті актуальною $€$ проблема захисту інтелектуального капіталу дипломатичної служби.

\section{АНА $І$ I ОСТАНHIX АОС $А$ ОЖЕНЬ І ПУБ $\Lambda$ ІКАЦЙ}

Тематику захисту інтелектуального капіталу дипломатичної служби, досліджує значна кількість науковців.
Зокрема наукові праці А.О. Гончарова, Б.І. Гуменюк, І.М. Білоус, М. Кулінич, Н.Л. Гавкалова, О.В. Попело, О.В. Щерба, О. Столяр, О.Ю. Амосов, Р. Марутян присвячені аналізу деяких аспектів захисту інтелектуального капіталу дипломатичної служби в рамках глобалізаційних процесів, які вплинули на генезис та становлення дипломатичного апарату та його зовнішньополітичну діяльність. Значну роботу з аналітичної оцінки дипломатичної служби здійснюють експерти Міністерства закордонних справ України.

\section{META I ЗАВААННЯ СТАTTI}

Метою роботи $€$ дослідження захисту інтелектуального капіталу дипломатичної служби, враховуючи інтелектуальну та освітню складові кандидатів, задля формування результативної діяльності. Для досягнення мети визначено такі завдання:

1) аналіз чинників впливу на інтелектуальний капітал;

2) проаналізувати кадровий склад дипломатичної служби України;

3) аналіз національного законодавства захисту прав інтелектуальної власності та капіталу дипломатичної служби.

Під час проведення дослідження було використано загальнонаукові й спеціальні методи дослідження, зокрема аналіз ісинтез, порівняння, узагальнення, системно-структурний аналіз, статистичний аналіз, політологічний та геополітичний методи.

\section{ВИК ААА ОСНОВНОГО МАТЕРІААУ АОС АIАЖЕНHЯ}

У сучасному світі зовнішньополітична діяльність дипломатичної служби $є$ невід'ємним компонентом державного службового апарату та має безпрецедентну галузеву специфріку, котра взаємопов'язана з ротацією особового кадрового складу дипломатичних службовців, оскільки в рамках системи Міністерства закордонних справ України (далі - МЗС) кадровий склад дипломатичного корпусу підпорядковується під періодичне переміщення, відрядження до дипломатичних установ розташованих за межами країни. Специфрічною особливістю дипломатичної служби є експансія зако- 
Таблиця 1. Кадровий склад закордонних дипломатичних установ за 2017-2020 рр.

\begin{tabular}{|c|c|c|c|c|c|c|c|c|}
\hline \multirow[t]{2}{*}{ Показники } & \multicolumn{4}{|c|}{$\begin{array}{c}\text { Затверджено у паспорті бюджетної } \\
\text { програми (ЗУПБП) }\end{array}$} & \multicolumn{4}{|c|}{ Фактичні результативні показники (ФРЗ) } \\
\hline & 2017 & 2018 & 2019 & 2020 & 2017 & 2018 & 2019 & 2020 \\
\hline $\begin{array}{l}\text { Кількість діючих закордонних } \\
\text { дипломатичних установ (ЗДУ) } \\
\text { України }\end{array}$ & 124 од. & 125 од. & 126 од. & 126 од. & 124 од. & 125 од. & 126 од. & 126 од. \\
\hline $\begin{array}{l}\text { Гранична штатна чисельність } \\
\text { працівників ЗДУ }\end{array}$ & 1399 чол. & 1394 чол. & 1394 чол. & 1394 чол. & 1399 чол. & 1394 чол. & 1394 чол. & 1394 чол. \\
\hline $\begin{array}{l}\text { Середньорічна чисельність } \\
\text { працівників ЗДУ (на штатних } \\
\text { посадах) }\end{array}$ & 1270 чол. & 1315 чол. & 1273 чол. & 1273 чол. & 1117 чол. & 1142 чол. & 1247 чол. & 1261 чол. \\
\hline $\begin{array}{l}\text { у тому числі дипломатичні } \\
\text { прачівники }\end{array}$ & - & 894 чол. & 856 чол. & - & - & 776 чол. & 839 чол. & - \\
\hline $\begin{array}{l}\text { адміністративно-технічні } \\
\text { прачівники }\end{array}$ & - & 298 чол. & 392 чол. & - & - & 259 чол. & 384 чол. & - \\
\hline обслуговуючий персонал & - & 123 чол. & 25 чол. & - & - & 107 чол. & 24 чол. & - \\
\hline $\begin{array}{l}\text { Чисельність працівників ЗДУ, які } \\
\text { виконують консульські функції }\end{array}$ & 275 чол. & 288 чол. & 307 чол. & 297 чол. & 288 чол. & 263 чол. & 295 чол. & 299 чол. \\
\hline
\end{tabular}

Джерело: сорормовано на основі джерела: [6].

нодавчих норм не тільки національного законодавства, крім того і міжнародного законодавства на дипломатичного службовця [1, с. 97].

Відповідно до правової доктрини трактування поняття "дипломатичної служби" тлумачать як спеціальний вид фрахової службової діяльності [2, с. 421]. У Законі України "Про дипломатичну службу" в статті 1 інтерпретується поняття "дипломатичної служби", яка визначається як фрахова діяльність громадян України, яка скерована на практичну імплементацію та реалізацію зовнішньополітичної діяльності України, захист національних інтересів країни у сорері міжнародних відносин, та включно прав та інтересів громадян та фрізичних та юридичних осіб України за кордоном [3].

Згідно з наданими повноваженнями спеціального органу державної влади, а саме МЗС, функціонування дипломатичного апарату відбувається виключно на державному рівні [4]. Закон України "Про дипломатичну службу України" встановлює специфрічні права та гарантії, особливі обов'язки, які являються визначальними ознаками дипломатичної служби та розповсюджуються на кадровий склад дипломатичного апарату. Цей Закон установлює порядок організації, визначає фрахов вимоги щодо штатних працівників дипломатичного апарату, надає розбірливу класифрікацію посад штатних працівників дипломатичної служби, встановлює основи правових засад що стосуються дипломатичного службовця та обмеження які стосуються штатних працівників, а також визначає основні поняття, завдання та функції дипломатичної служби. Дипломатична службає сферою міжнародних відносин, яка істотно вирізняється у всій сукупності від решти сорер громадського життя [3].

Одним з головних структурних елементів державної влади та державного управління $є$ дипломатична служба, де надзвичайний професіоналізм $є$ найважливішою взірцевою особливістю. Завжди працівників дипломатичної служби та дипломатів індивідуалізували всебічна ерудованість, дисциплінованість, освіченість, вправність результативно застосовувати новітні інформаційні технології, пронизливе усвідомлення історичної самобутності свого народу, оскільки ці моменти $\epsilon$ фундаментальними критеріями, які мають відношення до служби в апараті зовнішньополітичного відомства.
Функціональне вирішення політичних завдань, а також значної кількості завдань адміністративно-управлінського характеру щодо професійної асекурації високоефективної діяльності зовнішньополітичного відомства України здійснюється дипломатичною службою, де основною діяльністює документаційне, протокольне, адміністративно-технічне, правове, фрінансовоекономічне забезпечення зовнішньополітичних структур, а також в основі містить інформаційно-аналітичну, організаційно-управлінську та кадрову роботу.

Оскільки служба в дипломатичних установах є досить специфрічною сфрерою профресійної діяльності, де основною своєрідністю цієї роботи є:

1) націленість на захист інтересів, гарантування безпеки суспільства та держави на міжнародній арені;

2) не порушувати та захищати законні права та свободи громадян країни за кордоном;

3) убезпечення невимушеної участі громадян у державних справах;

4) стратегічний курс на імплементацію владних повноважень, а також політичних і соціальних державних завдань, а саме: інформаційно-аналітичних, організаційно-управлінських, фінансово-господарських завдань;

5) імплементація управлінських фрункцій державнополітичного адміністрування;

6) фрормування відповідних умов для безпечного та гідного життя кожної людини [2, с. 421].

Україна націлена на формування відповідної системи дипломатичної служби, яка тримає свій дипломатичний курс на приєднання, заохочення та утримання найкращих штатних працівників дипломатичного корпусу та санкціонує своєчасне позбавлення від професійно непридатних службовців. У прямо-пропорційній залежності знаходиться кар'єрний ріст дипломатичного службовця, а також його звання, класи та ранги від індивідуальних професійних досягнень, набутих професійноділових якостей та результативних показників роботи, які не залежать від статі, раси, національності, фрінансового положення, релігійних і політичних орієнтації, місця проживання, походження. Головними професійними рисами дипломатичного службовця $€$ наявність спеціальних знань, умінь та навичок; професійна підготовленість до виконання посадових обов'язків; відпові- 
дальне відношення до дипломатичної справи та високий рівень духовно-моральної культури, а також обов'язковою необхідністю для службовця $€$ наявність широкого політичного кругозору, знання іноземних мов, спостережливість та вміння розпізнати істину [5, с. 67].

Станом на 1 січня 2020 р. згідно з бюджетною програмою за рахунок державних коштів було забезпечено функціонування 126 ЗДУ України. Середньорічна чисельність працівників ЗДУ склала 1261 особа, а загальна чисельність штатних працівників, які здійснюють консульські функції, склала 299 осіб. Враховуючи суттєве збільшення обсягів консульських дій у країнах Східної Європи, було збільшено чисельність консульських працівників, за рахунок перерозподілу обов'язків серед працівників ЗДУ та забезпечено організацію виконання поставлених завдань на належному рівні (див. табл. 1) [6].

Розбіжності між фрактичними показниками чисельності та конфрірмованими результативними показниками обумовлені, зокрема часовими фракторами проведення конкурсів на заміщення вакантних посад та оформлення переможців конкурсів для направлення у закордонне відрядження [6]. Отже, середньорічна чисельність працівників закордонних дипломатичних установ згідно із фактичними результативними показниками за період 2017-2020 рр. має тенденцію до збільшення кількості штатних працівників.

На цьому етапі визначальним завданням дипломатичної служби інтелектуального капіталу $є$ нерозривне сполучення матеріального та інтелектуального капіталу та стимулювання інтелектуальної спрямованості роботи. Інтелектуальний капітал органів дипломатичної служби, під яким розуміють інтелектуальні ресурси, котрі реалізовані в сукупності наукових та загальних знань співробітників, котрі розробляють продукти інтелектуальної діяльності, котрі можуть належати як його винахіднику, так і іншим суб'єктам, та застосовуються задля отримання додаткової вартості, та стають одним із впливовіших чинників трудового потенціалу.

Трудовий потенціал органів державної служби визначається як трудові можливості дипломатичної служби, наявні нині і передбачувані на перспективу, що сорормовані в певних виробничих відносинах та умовах відтворення і характеризуються певною сукупністю кількісних і якісних ознак. Водночас науковці вважають, що максимізація трудового потенціалу можлива лише за наявності умов для формування та накопичення інтелектуального капіталу. Вітчизняний дослідник О. Кендюхов дав таке формулювання: інтелектуальний капітал це здатність створювати нову вартість на інтелектуальні ресурси, представлені людським і машинним інтелектами, а також інтелектуальними продуктами, створеними ним самостійно або залученими зі сторони як засоби створення нової вартості.

Отже, інтелектуальний капітал країни створюється на всіх рівнях адміністрування, але не можна вважати, що його значення буде отримане шляхом простого поєднання інтелектуального капіталу окремих підприємств, галузей тощо. Загальна вагомість інтелектуального капіталу відображає синергетичний ефект від сукупності інтелектуального капіталу. Інтелектуальний капітал усіх рівнів адміністрування створюється і за- стосовується під впливом множини чинників, які виділяють характерні ознаки його стану, розвитку та відтворення, і мають різний рівень впливу залежно від внутрішньої структури та особливостей його застосування [7].

Відповідно до загальновідомої класифрікації інтелектуальних ресурсів як спеціальний різновид ресурсу дипломатичного управління не представлено, проте визнаємо за доцільність виокремити цю групу ресурсів, до складу якої входять такі елементи:

- інтелект, який $є$ ступенем та рівнем фахових знань, досвіду, навичок, мобільності (здібність до перцепції новітньої інформації, проходження відповідного фахового навчання та перепідготовки, а також акомодація до сучасних кондицій) та інноваційності (здібність до генеративного мислення) дипломатичних службовців;

- кадри - це адміністративно-політична еліта, персонал дипломатичної служби та посадові особи дипломатичних органів влади;

- інформаційна інфраструктура дипломатичної служби складається із інформаційного забезпечення дипломатичної служби та інформаційно-комунікаційних технологій у системі дипломатичної служби;

- науково-експертне забезпечення дипломатичної служби.

Інтелектуальні ресурси дипломатичного управління реалізують ряд функцій, з-поміж яких необхідно відокремити такі:

- інформаційна - накопичення, систематизація й трансляція інформації, знань, вмінь та досвіду;

- експертно-аналітична - комплексний аналіз сорер життєдіяльності керуючого об'єкта, а також маніфестація тенденцій та закономірностей його розвитку, підготовка оцінок експертів та пропозицій стосовно шляхів вирішення проблем, а також сприяння імплементації керівних розв'язків та оцінювання імовірних наслідків від їхньої імплементації;

- прогностична - наукове обгрунтування оцінок можливих шляхів і консеквенцій розвитку об'єктів дипломатичного управління, при цьому враховуючи потрібні для цього ресурсів та засобів, моделювання дипломатичних перебігів та обставин, прогноз головних перешкод дипломатичного розвитку, формування комплексу прийомів для запобігання появи новітніх викликів;

- консалтингова - стратегічне консультування суб'єктів дипломатичного управління для підвищення результативності їх діяльності, розробка стратегії розвитку дипломатичних зносин та побудова результативної структури управління;

- моніторингова - дослідження та оцінка інформаційних потоків, аналіз якості дипломатичного управління та імплементація національних проєктів;

- інноваційна - стимулювання інновацій у дипломатичному управлінні.

Структуру інтелектуального ресурсу дипломатичного управління наведено на рисунку 1 [8, с. 284-285].

Отже, структурні елементи інтелектуального ресурсу $є$ неоднорідними внаслідок неоднорідності самого знання, котрі створені людським інтелектом, де деякі з них відображено у вигляді знань, не відокремлювальних від індивідуумів, котрі володіють даними знання, а інші фрормують свого роду відповідні кондиції викорис- 


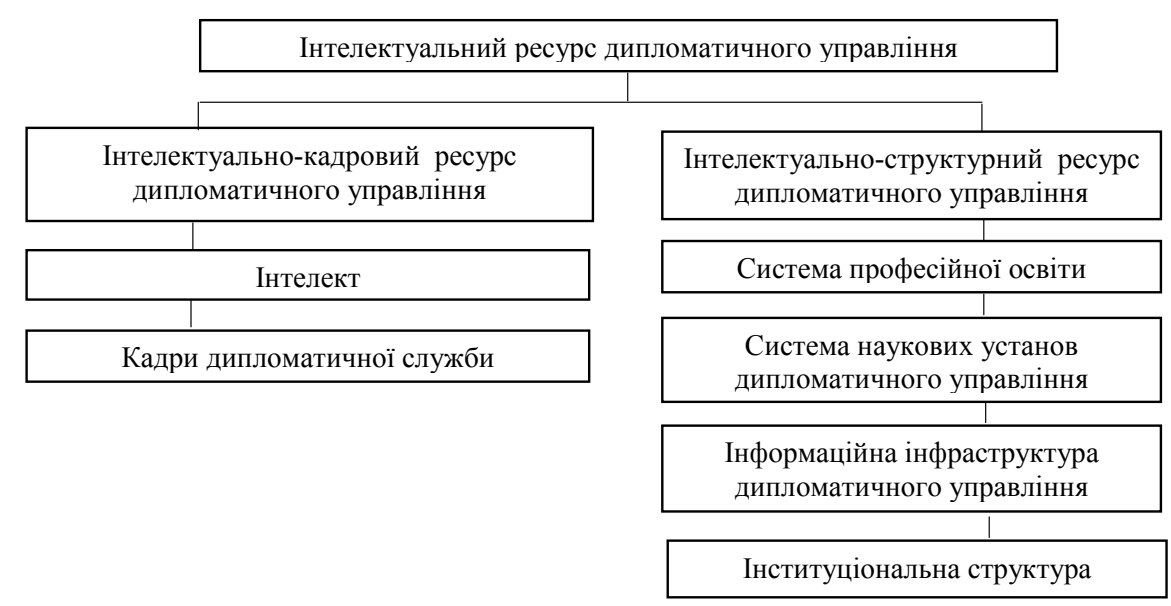

Рис. 1. Структура інтелектуального ресурсу дипломатичного управління

Джерело: сформовано на основі джерела: [8, с. 285].

тання даних знань з метою підвищення продуктивності праці, конкурентоспроможності дипломатичної служби [9, с. 67]. Отже, інтелектуальні ресурси - це засіб імплементації управлінських процесів, стратегічну ланку ресурсного потенціалу дипломатичного управління [8, с. 285].

Сьогодні дипломатія з мистецтва перетворилася на змістовну ефективну діяльність, де дипломати - це розгалужена висококваліфрікована інтелектуальна опора для керівництва держави, а прийняття доленосних рішень $€$ прерогативою керівництва, проте основну підготовчу роботу все ж таки повинні виконувати дипломати різних рангів. Оскільки дипломатія - це віддзеркалення життя, яка повинна не лише враховувати, а й керуватися такими категоріями, як профресіоналізм, порядність, патріотизм. Стратегічні цілі та завдання сучасного розвитку Дипломатичної академії визначаються фрункціями, котрі вона реалізує як галузевий навчальний заклад дипломатичної служби країни, та здійснює розвиток фахової компетентності співробітників дипломатичної служби та інших органів державної влади у сорері зовнішніх зносин. Головним завданням функціонування цього вищого навчального закладу сьогодні $\epsilon$ асекурація професіоналізації персоналу дипломатичної та державної служб у сфрері зовнішніх справ. Історично сфрормувалося, що під час фрормування органів зовнішніх зносин України до зовнішньополітичної діяльності та міжнародного співробітництва за- лучалися громадяни України, які передусім володіли іноземними мовами.

Саме $з$ метою надання державним службовцям, котрі працювали та працюють у сорері зовнішніх зносин України, відповідної якісної фахової підготовки відповідним Указом Президента України було створено Дипломатичну академію України. Щорічно в академії навчаються за спеціальністю "зовнішня політика" майже 150 слухачів і підвищують кваліфрікацію понад 600 державних службовців [10, с. 465-466].

За період 2017-2020 рр. згідно із фактичними результативними показниками та за затвердженою у паспорті бюджетною програмою 400 працівників дипломатичної служби підвищили кваліфікацію з іноземних мов та 600 працівників дипломатичної служби отримали професійне навчання (див. табл. 2).

Згідно з наданими статистичними даними на початок 2020 року здійснено заходи щодо мовної підготовки та профресійного навчання штатних працівників дипломатичної служби, на базі Дипломатичної академії України. Згідно з наданими статистичними даними на початок 2020 року здійснено заходи щодо мовної підготовки та професійного навчання штатних працівників дипломатичної служби, на базі Дипломатичної академії України, та крім того у прикладних навчальних закладах в Україні та за кордоном, а саме: 551 - в Дипломатичній академії України; 58 - в Українській школі урядування Національного агентства України з питань дер-

\section{Таблиця 2. Показники підвищення кваліфікації кадрів дипломатичної служби за 2017-2020 рр.}

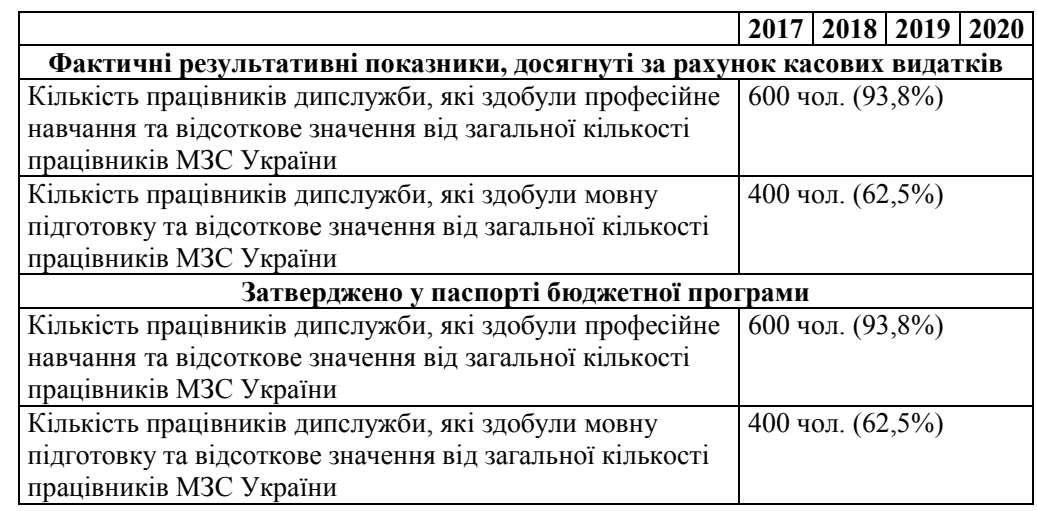

Джерело: сформовано на основі джерела: [6]. 
жавної служби; 20 - в Інституті підвищення кваліфікації керівних кадрів Національної академії державного управління при Президентові України; 56 - за кордоном [6].

Саме тому основою сучасної професійної підготовки у сорері зовнішніх зносин має стати набуття компетентності стратегічного мислення, стратегічного планування й управління. Випускник Дипломатичної академії повинен уміти кваліфріковано оцінити міжнародне становище та його вплив на країну, визначити адекватні зовнішнім загрозам і можливостям цілі та завдання зовнішньої та внутрішньої політики країни і запропонувати відповідні ефективні інструменти [10, с. 466-467].

Задля результативного формування і використання об'єктів права інтелектуальної власності являється присутність в країні відповідної державної системи правової охорони інтелектуальної власності. Вирішальне значення у Національній системі інтелектуальної власності приналежить Державній службі інтелектуальної власності України, та регулюються положеннями Конституції України, відповідними нормами Цивільного, Господарського, Митного, Кримінального кодексів України, Кодексу України про адміністративні правопорушення, та відповідними Законами України: "Про авторське право і суміжні права", "Про охорону прав на винаході і корисні моделі" та інші, включно приблизно 100 підзаконних актів, затверджених постановами КМУ.

Національне законодавство у сфері захисту інтелектуальної власності використало та реалізувало світовий досвід регулювання таких відносин, котрий визначено та імплементовано у наступних міжнародних конвенціях, як-от: Договір Всесвітньої організації інтелектуальної власності про авторське право, прийнятий Дипломатичною конференцією 20 грудня 1996 р., Гаазький акт 1969 року та Женевський акт, прийнятий 2 липня 1999 року та інші.

Головним напрямом міжнародної кооперації в зазначеній галузі $є$ виконання Україною відповідних міжнародних зобов'язань як держави члена Всесвітньої організації інтелектуальної власності. Репрезентанти країни приймають участь у діяльності профрільних комітетів та відповідних робочих груп цієї міжнародної організації. Не враховуючи імплементацію важливих рефрорм, які здійснюються в країні задля захисту прав інтелектуальної власності, повністю всі проблеми ще не ліквідувано. Головними порушення прав інтелектуальної власності виявляються у таких заходах:

1) незаконному виробництві, зберіганню, реалізації та транспортування дисків для лазерних систем зчитування та інших дій;

2) порушенні авторського права у мережі Інтернет;

3) незаконному застосування винаходу, корисної моделі, включаючи і привласнення авторство на них;

4) незаконному застосування відомостей, які є державною та дипломатичною таємницю, котра може спричинити істотну шкоду державі;

5. плагіаті та копіюванні.

Науковці виділяють такі причини виникнення у галузі інтелектуальної власності та виокремлюють наступні основні детермінанти: правового, економічного, політичного та організаційного характерів; духовноетичного та соціального (ідеологічного) характеру; тех- нічного характеру. З' ясовано, що за рівнем впливу на вчинення злочинів у цій сорері, детермінанти економічного та правового характеру у першу чергу обумовлюють їх вчинення.

В Україні поняття "захист прав інтелектуальної власності" містить у собі функціонування дипломатичних органів по визнанню, поновленню прав, включно усунення перепон, котрі перешкоджають імплементації прав та законних інтересів суб'єктів права у цій сорері, де предметом захисту $є$ не тільки особисте немайнове та майнове право інтелектуальної власності, а й інтереси, котрі знаходяться під захистом закону.

Захист інтелектуального капіталу дипломатичної служби поділяється на юрисдикційну і неюрисдикційну форми. У першому випадку застосовується судовий та адміністративний порядок захисту чи цивільно-правовий порядок. У останньому випадку захист відбувається без звернення по допомогу до державних органів, цей випадок стосується відмови укладача договору здійснити певні дії, про трансляцію майнових прав інтелектуальної власності.

На сучасному етапі розвитку країни не зафріксовано відповідну судову інстанцію з вирішення спорів у галузі інтелектуальної власності, котрі зобов'язують застосування специфічних знань, котрі імплементуються за методом здійснення судової експертизи, процедура здійснення якої затягує та здорожує процедуру захисту прав. Відсутність відповідної спеціалізованої установи негативно позначається на формуванні одностайної практики використання законодавства у сфері інтелектуальної власності. Формування відповідної судової інстанції з інтелектуальної власності України санкціонувало та вирішило б відповідні труднощі [11, с. 2425].

Правовий чинник має опосередкований вплив скоріше на використання, ніж на фрормування інтелектуального капіталу: законодавча база держави та правове регулювання прав інтелектуальної власності може 3 різним рівнем ефективності розвивати та використовувати його. Від рівня досконалості законодавства, його демократизації залежать основні тенденції та правила використання потенційних можливостей людини: відносини дипломатичних службовців між собою [7].

\section{ВИСНОВКИ 3 ПРОВЕАЕНОГО АОС $\triangle$ IАЖЕННЯ}

Проаналізувавши вищевикладене, можна узагальнити, що дипломатична служба відіграє важливу роль у формуванні зовнішньополітичного вектору та $є$ одним із ключових елементів у сорері державного управління, адже роль дипломатії, як знаряддя зовнішньої політики країни, завжди була значною. В сорері управління інтелектуальним капіталом дипломатичних службовців, підготовки та перепідготовки кадрів для дипломатичної служби можна зробити висновок, що сьогоднішня система управління такими кадрами в Україні $€$ неефективною.

Процес фрормування інтелектуального капіталу відбувається в умовах кризових явищ в економіці та соціальних суперечностей в суспільстві. Розглянуті чинники, що впливають на процеси формування та накопичення інтелектуального капіталу дипломатичної служ- 
би, є взаємопов'язаними, оскільки лише комплексі вони створюють необхідний стан. Виявлені чинники інтелектуального капіталу, рівень їх впливу дозволяють найбільш чітко формувати шляхи його підвищення, регулювати та розвивати в заданому напрямі, а також розробляти інструментарій оцінки інтелектуального капіталу, тобто науково обгрунтованої системи показників способів їх фріксування. Не розв'язані проблеми в галузі захисту прав інтелектуальної власності спричиняють фрормування негативного міжнародного іміджу України. Перспективами подальшого дослідження є удосконалення нормативно-правової бази та системи захисту прав у сфері інтелектуальної власності, стратегічні вектори розвитку зазначеної галузі з урахуванням зарубіжного досвіду, а також історичних, національних, ментальних чинників та традицій.

\section{Література:}

1. Столяр О. Розвиток дипломатичної служби в контексті європейського вибору України. Внутрішні й зовнішні аспекти євроінтеграційної політики України: матеріали конгресу за міжнар. участю (Київ, 17-18 жовт. 2013 р.) / за заг. ред. Ю.В. Ковбасюка, К.О. Ващенка, І.А. Грицяка, С.В. Загороднюка. Київ: НАДУ, 2013. C. $97-98$.

2. Гончарова А.О. Дипломатична служба як складова частина державної служби України. Актуальні проблеми державного управління. 2011. № 1. С. 420-424. URL: http://nbuv.gov.ua/UJRN/apdy_2011_1_51 (дата звернення 03.10.2020).

3. Про дипломатичну службу України: Закон України від 20.09.2001 № 2728-III / / Відомості Верховної Ради України. URL: http:/ / zakon4.rada.gov.ua/laws / show /2728-14 (дата звернення 03.10.2020).

4. Про затвердження Положення про Міністерство закордонних справ України: Указ Президента України від 06.04.2011 № 381/2011 // Відомості Верховної Ради України. URL: http:/ / zakon4.rada.gov.ua/laws / show /381/2011 (дата звернення 03.10.2020).

5. Гуменюк Б.І., Щерба О.В. Сучасна дипломатична служба: [навч. посіб.]. Київ: Либідь, 2001. 255 с.

6. Офріційний сайт Міністерства закордонних справ України. URL: https://mfa.gov.ua/ (дата звернення 03.10.2020).

7. Амосов О.Ю., Гавкалова Н.Л. Підготовка кадрів для державної служби як засіб формування інтелектуального капіталу державної служби. 2009. URL: http:/ /www.dridu.dp.ua/zbirnik/2009-02/09aoykdu.pdf (дата звернення 03.10.2020).

8. Марутян Р. Інтелектуальні ресурси державного управління в системі забезпечення державної влади. Збірник наукових праць Національної академії державного управління при Президентові України. 2012. Вип. 1. C. 277-286. URL: http://nbuv.gov.ua/UJRN/ znpnadu_2012_1_30 (дата звернення 03.10.2020).

9. Попело О.В. Інтелектуальний капітал: теоретичний аспект і сучасні тенденції розвитку в Україні. Економіка і регіон. 2015. № 2. C. 66-78. URL: http:// nbuv.gov.ua/UJRN/econrig_2015_2_14 (дата звернення 03.10.2020).

10. Кулінич М. Освітня підготовка дипломатів: сучасний контекст. Україна дипломатична. 2013. Вип. 14.
C. 464-475. URL: http://nbuv.gov.ua/UJRN/ukrdip_2013_14_30 (дата звернення 03.10.2020).

11. Білоус І.М. Захист прав інтелектуальної власності: український і зарубіжний досвід. Вісник Маріупольського державного університету. Серія: Право. 2016. Вип. 11. C. 20-27. URL: http://nbuv.gov.ua/UJRN/Vmdu_pr_2016_11_4 (дата звернення 03.10.2020).

\section{References:}

1. Stolyar, O. (2013), "Development of diplomatic service in the context of Ukraine's European choice", Vnutrishni j zovnishni aspekty ievrointehratsijnoi polityky Ukrainy [Internal and external aspects of Ukraine's European integration policy], Materialy konhresu za mizhnarodnoiu uchastiu [Proceedings of the congress with international participation], National Academy for Public Administration under the President of Ukraine, Kyiv, Ukraine, pp. 97-98.

2. Honcharova, A.O. (2011), "Diplomatic service as an integral part of the civil service of Ukraine", Aktual'ni problemy derzhavnoho upravlinnia, vol. 1. pp. 420-424, available at: http://nbuv.gov.ua/UJRN/apdy_2011_1_51 (Accessed 03 Oct 2020).

3. The Verkhovna Rada of Ukraine (2001), The Law of Ukraine "On the diplomatic service of Ukraine", available at: http://zakon4.rada.gov.ua/laws/show/2728-14 (Accessed 03 Oct 2020).

4. The Decree of the President of Ukraine (2011), "On approval of the Regulation on the Ministry of Foreign Affairs of Ukraine", available at: http://zakon4.rada.gov.ua/ laws/show /381/2011 (Accessed 03 Oct 2020).

5. Humeniuk, B.I. and Scherba, O.V. (2001), Suchasna dyplomatychna sluzhba [Modern diplomatic service], Lybid', Kyiv, Ukraine.

6. The official site of the Ministry of Foreign Affairs of Ukraine (2020), available at: https://mfa.gov.ua/ (Accessed 03 Oct 2020).

7. Amosov, O.Yu. and Havkalova, N.L. (2009), "Training for the civil service as a means of forming the intellectual capital of the civil service", available at: http:/ /www.dridu.dp.ua/zbirnik/2009-02/09aoykdu.pdf (Accessed 03 Oct 2020).

8. Marutian, R. (2012), "Intellectual resources of public administration in the system of state power", Zbirnyk naukovykh prats' Natsional'noi akademii derzhavnoho upravlinnia pry Prezydentovi Ukrainy, vol. 1, pp. 277-286, available at: http://nbuv.gov.ua/UJRN/znpnadu_2012_1_30 (Accessed 03 Oct 2020).

9. Popelo, O.V. (2015), "Intellectual capital: theoretical aspect and current trends in Ukraine", Ekonomika i rehion, vol. 2, pp. 66-78, available at: http://nbuv.gov.ua/ UJRN/econrig_2015_2_14 (Accessed 03 Oct 2020).

10. Kulinych, M. (2013), "Educational training of diplomats: modern context", Ukraina dyplomatychna, vol. 14, pp. 464-475, available at: http://nbuv.gov.ua/UJRN/ ukrdip_2013_14_30 (Accessed 03 Oct 2020).

11. Bilous, I.M. (2016), "Protection of intellectual property rights: Ukrainian and foreign experience", Visnyk Mariupol's'koho derzhavnoho universytetu. Seriia: Pravo, vol. 11, pp. $20-27$, available at: http://nbuv.gov.ua/ UJRN/Vmdu_pr_2016_11_4 (Accessed 03 Oct 2020). Cтаття надійüла дор редакщї 10.11.2020 p. 